\title{
Removal of Carbon Monoxide from Hydrogen-rich Fuels over $\mathrm{CeO}_{2}$-promoted $\mathrm{Pt} / \mathrm{Al}_{2} \mathrm{O}_{3}$
}

\author{
Akkarat Wongkaew ${ }^{1 *}$, Pichet Limsuwan ${ }^{2}$ \\ ${ }^{1}$ Department of Chemical Engineering, Faculty of Engineering, Burapha University, Chonburi, Thailand \\ ${ }^{2}$ Department of Physics, Faculty of Science, King Mongkut's University of Technology Thonburi, Bangkok, Thailand \\ Email: akkarat@buu.ac.th
}

Received May, 2013

\begin{abstract}
A comparative study of catalytic $\mathrm{CO}$ oxidation and selective $\mathrm{CO}$ oxidation over $\mathrm{Pt} / \mathrm{Al}_{2} \mathrm{O}_{3}$ and $\mathrm{CeO}_{2}$-promoted $\mathrm{Pt} / \mathrm{Al}_{2} \mathrm{O}_{3}$ catalysts has been investigated for the removal of a trace amount of $\mathrm{CO}$ from the reformed gas. The catalysts were prepared by sol gel and incipient wetness impregnation. $\mathrm{CO}$ oxidation and selective $\mathrm{CO}$ oxidation were carried out with a $5 \% \mathrm{Pt} / \mathrm{Al}_{2} \mathrm{O}_{3}$ and a $5 \% \mathrm{Pt} / 15 \% \mathrm{CeO}_{2} / \mathrm{Al}_{2} \mathrm{O}_{3}$. The presence of $15 \% \mathrm{CeO}_{2}$ in the $5 \% \mathrm{Pt} / \mathrm{Al}_{2} \mathrm{O}_{3}$ dramatically improves the activities to $\mathrm{CO}$ oxidation and selective $\mathrm{CO}$ oxidation at low temperature $\left(<180^{\circ} \mathrm{C}\right)$. FTIR results indicate that $\mathrm{CO}$ could react with lattice oxygen from ceria and release $\mathrm{CO}_{2}$ as a product. Low space velocity would obtain high $\mathrm{CO}$ conversion at low temperatures while high space velocity would obtain high $\mathrm{CO}$ conversion at high temperatures. The results also show that a $5 \% \mathrm{Pt} / 15 \% \mathrm{CeO}_{2} / \mathrm{Al}_{2} \mathrm{O}_{3}$ can completely oxidize $1 \% \mathrm{CO}$ at $180^{\circ} \mathrm{C}$ with selectivity of $52 \%$ and space velocity of $70,000 \mathrm{~cm}^{3} \cdot \mathrm{g}^{-1} \cdot \mathrm{h}^{-1}$. Under the realistic gas feed with $1 \% \mathrm{O}_{2}$, this catalyst is very stable and retains its activity and selectivity at $180^{\circ} \mathrm{C}$ during $72 \mathrm{~h}$.
\end{abstract}

Keywords: $\mathrm{CO}$ Oxidation; $\mathrm{CeO}_{2}$-Pt/alumina; $\mathrm{CO}$ Adsorption; Selective $\mathrm{CO}$ Oxidation; Fuel Processing

\section{Introduction}

The polymer-electrolyte-membrane fuel cell (PEMFC) has been attracting significant attention in several applications including electric vehicles and residential powergenerations. This is because of its many attractive features such as high power density, rapid start-up, and high efficiency $[1,2]$. As the PEMFCs utilize hydrogen gas as a fuel and since hydrogen can be produced by means of a fuel reformer followed by water gas shift reaction for further conversion of $\mathrm{CO}$ to $\mathrm{H}_{2}$, carbon monoxide is always present in the hydrogen stream. Generally, catalytic steam reforming of methanol or partial oxidation of gasoline followed by water gas shift reaction will produce a gas stream with $40 \%-75 \% \mathrm{H}_{2}, 15 \%-20 \% \mathrm{CO}_{2}$, $\sim 10 \% \mathrm{H}_{2} \mathrm{O}, 0-25 \% \mathrm{~N}_{2}$ and $0.5 \%-1.0 \% \mathrm{CO}$. This amount of $\mathrm{CO}$ contained in the reformed gas is high enough to poison the Pt anode of PEM fuel cells and in turn dramatically degrades the fuel cell potential and energy conversion efficiency $[3,4]$. Experimentally, it has been found that the tolerable level of $\mathrm{CO}$ without harmful effects is about $10 \mathrm{ppm}$ [5]. This means the $0.5 \%-1.0 \% \mathrm{CO}$ needs to be reduced to $10 \mathrm{ppm}$ or less in order to increase the use of proton exchange membrane (PEM) fuel cells running with on-board generated hydrogen. The most economical and straightforward technique for this pur- pose is selective catalytic oxidation of $\mathrm{CO}$ in the $\mathrm{H}_{2}$-rich reformed gas using $\mathrm{O}_{2}$ or preferential oxidation (PROX). This method needs a suitable catalyst to enhance the CO oxidation reaction with minimal oxidation of hydrogen which is the desired fuel. The crucial requirement for the PROX re- actor is a high CO conversion with high selectivity. A number of catalysts have been investigated for the PROX reaction [6-10]. Noble metals supported on alumina such as $\mathrm{Pt}, \mathrm{Au}, \mathrm{Ru}$ and $\mathrm{Pd}$, have been proposed as ideal catalysts for PROX reaction, especially $\mathrm{Pt} / \mathrm{Al}_{2} \mathrm{O}_{3}$, $\mathrm{Pt} / \mathrm{Fe}_{2} \mathrm{O}_{3} / \mathrm{Al}_{2} \mathrm{O}_{3}, \mathrm{Pt} / \mathrm{CeO}_{2}, \mathrm{Pt} / \mathrm{CeO}_{2} \mathrm{ZrO}_{2}, \mathrm{Pt} /$ zeolite [11-13]. An improvement in the selectivity at low temperatures is needed. Oxidation of $\mathrm{CO}$ on alumina-supported Pt catalysts is known to take place via the Langmuir-Hinshel- wood mechanism. Kahlich et al. [14] studied the kinetics of selective $\mathrm{CO}$ oxidation in $\mathrm{H}_{2}$-rich gas on $\mathrm{Pt} / \mathrm{Al}_{2} \mathrm{O}_{3}$ and observed that $\mathrm{CO}$ conversion never reached $100 \%$ for a $0.5 \% \mathrm{Pt} / \mathrm{Al}_{2} \mathrm{O}_{3}$. The maximum $\mathrm{CO}$ conversion was $\sim 80 \%$ at temperatures as high as 250 ${ }^{\circ} \mathrm{C}$. Other studies reported that $\mathrm{CO}$ conversion occurred in the reaction temperature range of $200^{\circ} \mathrm{C}-250^{\circ} \mathrm{C}$ [15] or else needed high oxygen concentration for complete elimination of $\mathrm{CO}$, corresponding to lower selectivity. We have previously [16] investigated the catalytic activity of $2 \% \mathrm{Pt} / \mathrm{Al}_{2} \mathrm{O}_{3}$, which was prepared by the sol-gel method, in selective $\mathrm{CO}$ oxidation reaction under the 
excess $\mathrm{H}_{2}$ gas stream. We found that $2 \% \mathrm{Pt}$ was well dispersed in alumina supports. Therefore, it can selectively oxidize $\mathrm{CO}$ down to ppm level with constant selectivity and high space velocity. The performance of $\mathrm{Pt}$ catalysts can be improved by modifying supports such as adding alkali metals into supports [17] or by promoting with other metal oxides such as $\mathrm{Fe}_{2} \mathrm{O}_{3}$ or $\mathrm{CeO}_{2}$ [18]. Serre, et al. [19] found that the presence of $\mathrm{CeO}_{2}$ in a $2 \% \mathrm{Pt} / \mathrm{Al}_{2} \mathrm{O}_{3}$ after a reductive pretreatment drastically enhanced the activity of the catalyst to $\mathrm{CO}$ oxidation. The promoting effect of ceria was attributed to the enhancement of the metal dispersion and the stabilization of $\mathrm{Al}_{2} \mathrm{O}_{3}$ support toward thermal sintering. Moreover, ceria can be a chemically active component, working as an oxygen store that releases lattice oxygen in the presence of reductive gases and re- placement of the lattice oxygen with oxygen gas when oxygen gas is present in excess [20]. Parinyaswan et al. [21] investigated the performance of $\mathrm{Pt}-\mathrm{Pd} / \mathrm{CeO}_{2}$ catalysts for selective $\mathrm{CO}$ oxidation. This catalyst could maximally convert $83 \% \mathrm{CO}$ to $\mathrm{CO}_{2}$ with selectivity of $60 \%$ at $90{ }^{\circ} \mathrm{C}$ with a gas feed containing $1 \% \mathrm{CO}, 1 \% \mathrm{O}_{2}, 25 \% \mathrm{CO}_{2}$ and $10 \% \mathrm{H}_{2} \mathrm{O}$. This means there would still be 1,700 ppm of CO left in the gas feed and this gas could dramatically deplete the efficiency of a PEM fuel cell in a very short time. The authors suggest a multi-stage reactor to reduce $\mathrm{CO}$ to below $10-100 \mathrm{ppm}$ for the use of this catalyst with PEM fuel cells. Silva et al. [22] studied the effect of the presence of ceria with Pt over alumina catalysts for the partial oxidation of methane reaction. They reported that the addition of ceria in alumina led to the formation of a homogenous solid solution, which exhibited a high-oxygen storage capacity. Brown et al. [23] compared the activities of Pt over alumina with ceria-promoted $\mathrm{Pt}$ over alumina in the production of hydrogen from methanol decomposition. They reported that promoting with ceria had a positive effect on activity and selectivity. Indeed, the use of ceria coupled with alumina as a support for Pt might enhance the catalytic selective $\mathrm{CO}$ oxidation of platinum over alumina catalysts. Son et al. [24,25] investigated the performance of $\mathrm{Ce}-\mathrm{Pt} / \gamma-\mathrm{Al}_{2} \mathrm{O}_{3}$ for selective oxidation of $\mathrm{CO}$ in $\mathrm{H}_{2}$ for PEFCs. They found that the addition of $5 \% \mathrm{Ce}$ in the Pt over alumina dramatically enhanced $\mathrm{CO}$ conversion and selectivity at low temperatures. The catalyst completely converted $1 \% \mathrm{CO}$ to $\mathrm{CO}_{2}$ at $200^{\circ} \mathrm{C}$ with $50 \%$ selectivity. Although the effect of other gases such as $\mathrm{CO}_{2}$ and $\mathrm{H}_{2} \mathrm{O}$ was stud- ied, their gas compositions containing $1 \% \mathrm{CO}, 2.3 \% \mathrm{H}_{2} \mathrm{O}, 10.09 \% \mathrm{CO}_{2}$ and $\mathrm{H}_{2}$ as balance were far from a realistic gas composition containing $40 \%-75 \% \mathrm{H}_{2}, 0.5 \%-2.0 \% \mathrm{CO}, 15 \%-20 \% \mathrm{CO}_{2}, 10 \% \mathrm{H}_{2} \mathrm{O}$ and $0-25 \% \mathrm{~N}_{2}$ by volume. Therefore, the activity of promoted platinum over alu- mina with ceria for preferential CO oxidation still needs to be investigated.

In order to obtain a better understanding of the activity of the ceria promoted platinum alumina catalyst to the selective $\mathrm{CO}$ oxidation, $5 \% \mathrm{Pt} / 15 \% \mathrm{CeO}_{2} / \mathrm{Al}_{2} \mathrm{O}_{3}$ and $5 \%$ $\mathrm{Pt} / \mathrm{Al}_{2} \mathrm{O}_{3}$ catalysts were tested for their activities to both $\mathrm{CO}$ oxidation in $\mathrm{H}_{2}$ free-stream and $\mathrm{CO}$ oxidation in the presence of excess $\mathrm{H}_{2}$-containing feed stream and the obtained results were compared with others reported in literatures. All supports in this work were prepared by sol gel method. The CO coverage of the catalysts was also studied using FTIR. The FTIR results were used to explain the enhancement of catalyst activity in the presence of ceria. It should be pointed out that all gases containing in reformed gas affect to the selectivity to $\mathrm{CO}$ oxidation of the catalysts as reported in literatures. Therefore, the effect of space velocity on the activity of the catalyst was investigated. These results will lead us to the proper operating conditions in order to obtain high selectivity and high $\mathrm{CO}$ conversion of ceria promoted $\mathrm{Pt}$ alumina catalyst.

\section{Experimental}

\subsection{Catalyst Preparation}

A cerium aluminum oxide supported platinum $(\mathrm{Pt})$ catalyst with $5.0 \mathrm{wt} \%$ Pt loading was prepared by sol gel technique [26] and incipient wetness impregnation. Aluminum is protoxide; cerium (III) acetate and hydrogen hex anchor oplatinate (IV) hydrate were obtained from Aldrich. Preparation of supports containing cerium aluminum oxide began with dissolving the desired amount of aluminum is protoxide in hot demonized water at $80^{\circ} \mathrm{C}$. After 30 min of aging with continuous stirring, nitric acid $\left(\mathrm{HNO}_{3}\right)$ was added to start the hydrolysis reaction resulting in a fibrillar sol. Then, the known amount of cerium (III) acetate was incorporated into the solution at room temperature. The solution was stirred overnight to obtain uniformity. The obtained solution was heated to $60^{\circ} \mathrm{C}$ and kept at this temperature until gelation occurred. The gel was dried in air at $110^{\circ} \mathrm{C}$ overnight, and then calcined at $500^{\circ} \mathrm{C}$ for 13 hours. After calcination, the resulting powder was ground and sieved to obtain a 100-140 mesh powder. Incipient wetness impregnation was used to deposit platinum into the support. With this method, a desired amount of solution of hydrogen hexachloroplatinate (IV) hydrate was added into a cerium alumina support and then mixed together until the mixture uniformly. The obtained solid was dried in air at $110^{\circ} \mathrm{C}$ overnight, and then calcined at $500^{\circ} \mathrm{C}$ for 13 hours. The final powder was $5 \% \mathrm{Pt} / 15 \% \mathrm{CeO}_{2} / \mathrm{Al}_{2} \mathrm{O}_{3}$. In this work, the activity of this catalyst was compared with activity of a $5 \% \mathrm{Pt} / \mathrm{Al}_{2} \mathrm{O}_{3}$. For a $5 \% \mathrm{Pt} / \mathrm{Al}_{2} \mathrm{O}_{3}$ analogous preparation techniques were used such that the $\mathrm{Al}_{2} \mathrm{O}_{3}$ support was prepared by sol gel and $\mathrm{Pt}$ was impregnated in the support by incipient wetness impregnation. Before testing the activities of these catalysts, the catalysts were purged with $\mathrm{H}_{2}$ at $400^{\circ} \mathrm{C}$ for $5 \mathrm{hrs}$. 


\subsection{Characterization}

The BET surface area and average pore radius of catalysts were determined with adsorption-desorption isotherms of $\mathrm{N}_{2}$ at $77 \mathrm{~K}$ using a MicroMeritics ASAP 2010 instrument. Average crystalline sizes of oxides were determined by Scherrer's equation using the X-ray line broadening from X-ray diffraction, Bruker AXS model D 8 Discover equipped with a $\mathrm{CuK} \alpha$ radiation with a nickel filter. Diffraction intensity was measured in the 2 theta ranges between $20^{\circ}$ and $85^{\circ}$, with a step of $0.02^{\circ}$ for $8 \mathrm{~s}$ per point.

\subsection{Catalytic Activity}

$\mathrm{CO}$ oxidation and $\mathrm{CO}$ oxidation in the $\mathrm{H}_{2}$-rich stream was performed in a fixed-bed reactor. The reaction temperatures inside the reactor were measured with a K-type thermocouple placed on the top of the catalyst bed and were controlled by a temperature controller (OMEGA: CN3251). The amount of catalyst used in each run was $68 \mathrm{mg}$. The total gas flow rates of the reaction mixture were $40 \mathrm{~cm}^{3} \cdot \mathrm{min}^{-1}$ and $80 \mathrm{~cm}^{3} \cdot \mathrm{min}^{-1}$, corresponding to the space velocity of $70,000 \mathrm{~cm}^{3} \cdot \mathrm{g}^{-1} \cdot \mathrm{h}^{-1}$ and of 35,000 $\mathrm{cm}^{3} \cdot \mathrm{g}^{-1} \cdot \mathrm{h}^{-1}$, respectively. For CO oxidation, the activity tests were conducted with a feed mixture of $1 \% \mathrm{CO}, 1 \%$ $\mathrm{O}_{2}$ and $\mathrm{He}$ as balance. For selective $\mathrm{CO}$ oxidation, a feed mixture contained $1 \% \mathrm{CO}, 0.5 \%-1 \% \mathrm{O}_{2}, 0-10 \% \mathrm{H}_{2} \mathrm{O}$, $0-20 \% \mathrm{CO}_{2}, 55 \% \mathrm{H}_{2}$ and $\mathrm{He}$ as balance. A volumetric flow controller with an accuracy of $0.5 \mathrm{~cm}^{3} \cdot \mathrm{min}^{-1}$ was used for measuring the total gas flow rate at the bypass (for calibration purposes) and at the outlet of the reactor.

A Varian CP-4900 micro gas chromatograph (micro GC) equipped with 2 channels (A and B) was used for analysis of the outlet gas compositions from the reactor. Channel A was used to detect $\mathrm{H}_{2}, \mathrm{O}_{2}, \mathrm{CO}$ and $\mathrm{CH}_{4}$ by a Molsieve 5A PLOT column. Channel B was used to detect $\mathrm{CO}_{2}$ by a PoraPLOT Q column. Along with GC, FTIR was used to detect $\mathrm{CO}$ at low concentrations (ppm level) in the outlet gas from the reactor. Because water deteriorates the performance of these columns, an ice cooled water condenser was used to remove water from the gas streams before entering the GC and FTIR.

The CO conversion was obtained by comparing the $\mathrm{CO}$ concentration in the feed measured at the bypass line and the $\mathrm{CO}$ concentration in the outlet stream from the reactor. Selectivity was defined as the ratio of oxygen consumed by $\mathrm{CO}$ oxidation to the total oxygen consumption (obtained by subtracting the $\mathrm{O}_{2}$ concentration at the reactor outlet from the $\mathrm{O}_{2}$ concentration in the feed). The amount of $\mathrm{O}_{2}$ not used in the $\mathrm{CO}$ oxidation reaction was assumed to oxidize $\mathrm{H}_{2}$ in the $\mathrm{H}_{2}$ oxidation reaction. Importantly, there was no methane formation observed under reaction conditions performed in this study.

\section{Results and Discussion}

\subsection{Characterization of the Catalysts}

The alumina support prepared via the sol gel method yielded a BET area of $227.8 \mathrm{~m}^{2} / \mathrm{g}$ with an average pore size of $5.3 \mathrm{~nm}$ while the sol gel made $15 \% \mathrm{CeO}_{2} / \mathrm{Al}_{2} \mathrm{O}_{3}$ had a BET area of $230.0 \mathrm{~m}^{2} / \mathrm{g}$ with an average pore size of $5.2 \mathrm{~nm}$. Pt crystalline sizes were estimated from the line broadening of $\mathrm{Pt}(111)$ peaks. For both a $5 \% \mathrm{Pt} / \mathrm{Al}_{2} \mathrm{O}_{3}$ catalyst and a $5 \% \mathrm{Pt} / 15 \% \mathrm{CeO}_{2} / \mathrm{Al}_{2} \mathrm{O}_{3}$ catalyst, no $\mathrm{Pt}$ (111) peaks were observed indicating that Pt metal was well impregnated and dispersed on the supports for both catalysts. For ceria structure in a $5 \% \mathrm{Pt} / 15 \% \mathrm{CeO}_{2} / \mathrm{Al}_{2} \mathrm{O}_{3}$ fresh catalyst reduced under hydrogen, $\mathrm{XRD}$ results matched with those for $\mathrm{CeO}_{2}$ with average $\mathrm{CeO}_{2}$ crystallite sizes of $\sim 6.8 \mathrm{~nm}$. Dispersions measured by $\mathrm{CO}$ chemisorption were $48 \%$ for the $5 \% \mathrm{Pt} / \mathrm{Al}_{2} \mathrm{O}_{3}$ and $54 \%$ for the $5 \% \mathrm{Pt} /$ $15 \% \mathrm{CeO}_{2} / \mathrm{Al}_{2} \mathrm{O}_{3}$.

\subsection{Activity Tests for CO Oxidation with Free-H2 Gas Stream}

The two catalysts were tested for their activities in $\mathrm{CO}$ oxidation as a function of temperature under gas feed containing $1 \% \mathrm{CO}, 1 \% \mathrm{O}_{2}$ and $\mathrm{He}$ as balance as seen in Figure 1.

At $100{ }^{\circ} \mathrm{C}$ the integral conversions were $2 \%$ and $10 \%$ over the $5 \% \mathrm{Pt} / \mathrm{Al}_{2} \mathrm{O}_{3}$ and the $5 \% \mathrm{Pt} / 15 \% \mathrm{CeO}_{2} / \mathrm{Al}_{2} \mathrm{O}_{3}$ catalysts. Increasing the temperature to $150^{\circ} \mathrm{C}$ increased the CO conversion from $2 \%$ to $27 \%$ for the $5 \% \mathrm{Pt} / \mathrm{Al}_{2} \mathrm{O}_{3}$ and from $10 \%$ to $60 \%$ for the $5 \% \mathrm{Pt} / 15 \% \mathrm{CeO}_{2} / \mathrm{Al}_{2} \mathrm{O}_{3}$. Further increasing reaction temperature to $170^{\circ} \mathrm{C}$ increased the CO conversion to $70 \%$ for the $5 \% \mathrm{Pt} / \mathrm{Al}_{2} \mathrm{O}_{3}$ and to $98.9 \%$ for the $5 \% \mathrm{Pt} / 15 \% \mathrm{CeO}_{2} / \mathrm{Al}_{2} \mathrm{O}_{3}$. Finally, $\mathrm{CO}$ completely converted to $\mathrm{CO}_{2}$ at $180^{\circ} \mathrm{C}$ for both catalysts. Clearly, the catalyst containing ceria showed better activity in $\mathrm{CO}$ oxidation, especially at low temperatures. For the $5 \% \mathrm{Pt} / \mathrm{Al}_{2} \mathrm{O}_{3}$, it has been known that $\mathrm{CO}$ strongly chemisorbs over Pt sites from room temperatures to $150^{\circ} \mathrm{C}$

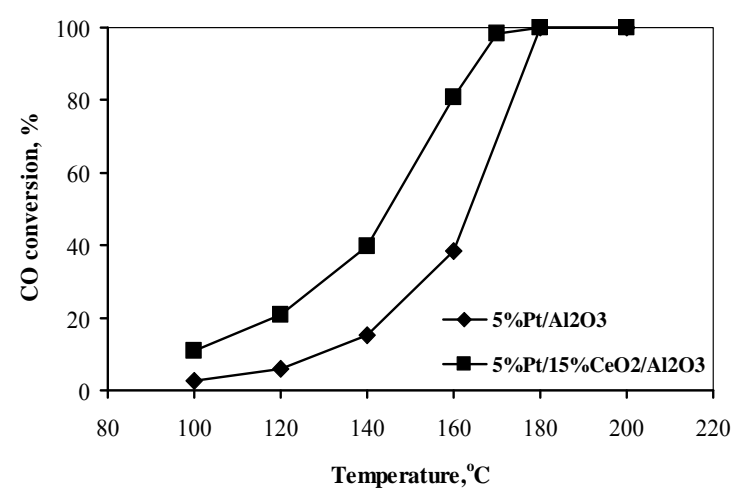

Figure 1. Activities of platinum over alumina and promoted platinum over alumina catalysts to $\mathrm{CO}$ oxidation. Gas composition: $1 \% \mathrm{CO}, 1 \% \mathrm{O}_{2}$ and $\mathrm{He}$ as balance. 
[14,27]. At these temperatures, the competition between $\mathrm{CO}$ molecules and $\mathrm{O}_{2}$ molecules over the active sites is crucial. The reaction occurs when $\mathrm{O}_{2}$ molecules adsorb and dissociate next to $\mathrm{CO}$ molecules. At tem- peratures less than $150^{\circ} \mathrm{C}$, Pt sites are occupied by $\mathrm{CO}$ molecules. This leads to low activity of platinum over alumina catalysts in the $\mathrm{CO}$ oxidation reaction. Increas- ing reaction temperature above $150^{\circ} \mathrm{C}$ dramatically in- creases the rate of reaction due to desorption of $\mathrm{CO}$ molecules from the active sites and leaving available sites for $\mathrm{O}_{2}$ molecules to be adsorbed. The addition of ceria enhances the rate of reaction of the catalyst. This is due to the oxygen storage property proposed as following [28]:

$$
\begin{aligned}
\mathrm{CO}_{a d s}+2 \mathrm{CeO}_{2} & \rightarrow \mathrm{CO}_{2}+*+\mathrm{Ce}_{2} \mathrm{O}_{3} \\
\frac{1}{2} \mathrm{O}_{2}+* & \rightarrow \mathrm{O}_{a d s} \\
\mathrm{O}_{a d s}+\mathrm{Ce}_{2} \mathrm{O}_{3} & \rightarrow 2 \mathrm{CeO}_{2}+*
\end{aligned}
$$

where "*" stands for an adsorption site on platinum and "ads" for an adsorbed species. From this model, the key point of high activity of the $5 \% \mathrm{Pt} / 15 \% \mathrm{CeO}_{2} / \mathrm{Al}_{2} \mathrm{O}_{3}$ catalyst at low reaction temperatures $\left(<150^{\circ} \mathrm{C}\right)$ results from a capacity of ceria to switch between the two-oxidation states $\mathrm{Ce}^{4+}$ and $\mathrm{Ce}^{3+}$. $\mathrm{Ce}^{3+}$ returns back to $\mathrm{Ce}^{4+}$ by gaseous oxygen molecules. This phenomenon occurs even at room temperature. However, $170^{\circ} \mathrm{C}$ is high enough for $\mathrm{CO}$ molecules to desorbs from active sites and leave the active sites available for other reactant molecules to be adsorbed and reacted [29]. Therefore, both catalysts performed comparably above $170^{\circ} \mathrm{C}$. FTIR was used to check the chemisorbed $\mathrm{CO}$ species. The results are shown in Figure 2. Before the test, the catalyst pellet diluted with $\mathrm{KBr}$ was purged with helium at $200^{\circ} \mathrm{C}$ until catalyst surface was clean. Then, the sample was cooled to $100^{\circ} \mathrm{C}$ under a helium purge. After the temperature of the sample reached $100^{\circ} \mathrm{C}$, the sample was purged with gas stream containing $1 \% \mathrm{CO}$ balance with helium. The adsorption of $\mathrm{CO}$ over the catalyst sample was recorded.

Figure 2(a) shows the $\mathrm{CO}$ adsorption over the $5 \% \mathrm{Pt} /$ $15 \% \mathrm{CeO}_{2} / \mathrm{Al}_{2} \mathrm{O}_{3}$ pellet. A strong peak at $2062 \mathrm{~cm}^{-1}$ was observed. This peak corresponds to $\mathrm{CO}$ adsorbed over $\mathrm{Pt} / \mathrm{CeO}_{2} / \mathrm{Al}_{2} \mathrm{O}_{3}$ [30]. Other peaks at $2395-2312 \mathrm{~cm}^{-1}$ were also observed and these peaks indicate the presence of gas phase $\mathrm{CO}_{2}$. The intensity of the $\mathrm{CO}_{2}$ band slowly decreased with time and finally disappeared. The formation of $\mathrm{CO}_{2}$ was due to $\mathrm{CO}$ oxidation reaction and the $\mathrm{O}_{2}$ reactant must have come from lattice of $\mathrm{CeO}_{2}$. This result was in agreement with a model of oxygen transport in $\mathrm{Pt} /$ ceria catalyst [31]. Next, the same experiment was carried out with the $5 \% \mathrm{Pt} / \mathrm{Al}_{2} \mathrm{O}_{3}$. The results are shown in Figure 2(b). A strong peak at $2085 \mathrm{~cm}^{-1}$ was observed. This peak corresponds to $\mathrm{CO}$ adsorbed on Pt with neighboring oxidized Pt [32]. Unlike platinum over ceriapromoted alumina catalyst, no peak of $\mathrm{CO}_{2}$ gas phase was observed. This means that in the absence of gas phase $\mathrm{O}_{2}$ no $\mathrm{CO}$ oxidation reaction occurs with this catalyst. The $\mathrm{CO}$ adsorbed on Pt peak for promoted Pt catalyst appeared at $2062 \mathrm{~cm}^{-1}$ while that of $\mathrm{Pt} / \mathrm{Al}_{2} \mathrm{O}_{3}$ appeared at $2085 \mathrm{~cm}^{-1}$ [29,32]. The downward shift of CO adsorbed wave number may be due to inducing of C-O bond weakening for $\mathrm{CO}$ adsorbed on $\mathrm{Pt}$ by $\mathrm{Ce}$ [19]. The reduction of the bond strength of adsorbed $\mathrm{CO}$ makes it more reactive with an oxygen atom from ceria lattice into $\mathrm{CO}$ adsorbed near $\mathrm{Pt}-\mathrm{CeO}_{2}$ interface followed by desorption of $\mathrm{CO}_{2}$ leaving Pt site available for other gas molecules. Therefore, the presence of a small amount of ceria could enhance the activity of platinum over alumina due to its oxygen storage property.

\subsection{Effect of Ceria on the Activity of Catalysts}

The effect of ceria on the activity of catalysts was shown in Figure 3.

Figure 3(a) shows the activities of the two catalysts as function of reaction temperature for a dry gas composition of $1 \% \mathrm{CO}, 1 \% \mathrm{O}_{2}, 55 \% \mathrm{H}_{2}$ and $\mathrm{He}$ as balance. At 110 ${ }^{\circ} \mathrm{C}$, CO conversions were $46 \%$ and $60 \%$ over the $5 \%$ $\mathrm{Pt} / \mathrm{Al}_{2} \mathrm{O}_{3}$ and the $5 \% \mathrm{Pt} / 15 \% \mathrm{CeO}_{2} / \mathrm{Al}_{2} \mathrm{O}_{3}$ catalysts. Increasing reaction temperatures further to $180^{\circ} \mathrm{C}$ led to dramatic increases in $\mathrm{CO}$ conversion from $46 \%$ to $90 \%$ for the $5 \% \mathrm{Pt} / \mathrm{Al}_{2} \mathrm{O}_{3}$ and from $60 \%$ to $99.3 \%$ for the $5 \% \mathrm{Pt} / 15 \% \mathrm{CeO}_{2} / \mathrm{Al}_{2} \mathrm{O}_{3}$. At $190^{\circ} \mathrm{C}, \mathrm{CO}$ conversion reached a maximum of approximately $99.97 \%$ for the $5 \% \mathrm{Pt} / 15 \%$ $\mathrm{CeO}_{2} / \mathrm{Al}_{2} \mathrm{O}_{3}$ while $\mathrm{CO}$ conversion reached a maximum of approximately $93.70 \%$ for the $5 \% \mathrm{Pt} / \mathrm{Al}_{2} \mathrm{O}_{3}$. Further increasing reaction temperature to $230^{\circ} \mathrm{C}$ resulted in decreases in $\mathrm{CO}$ conversion to $57 \%$ for the $5 \% \mathrm{Pt} / \mathrm{Al}_{2} \mathrm{O}_{3}$ and $89 \%$ for the $5 \% \mathrm{Pt} / 15 \% \mathrm{CeO}_{2} / \mathrm{Al}_{2} \mathrm{O}_{3}$. Figure $3($ b) shows oxygen consumption as a function of reaction temperature. For the $5 \% \mathrm{Pt} / \mathrm{Al}_{2} \mathrm{O}_{3}, \mathrm{O}_{2}$ was quickly consumed by the reactions. $\mathrm{O}_{2}$ conversion increased from $79 \%$ to $100 \%$ when reaction temperature increased from $110^{\circ} \mathrm{C}$

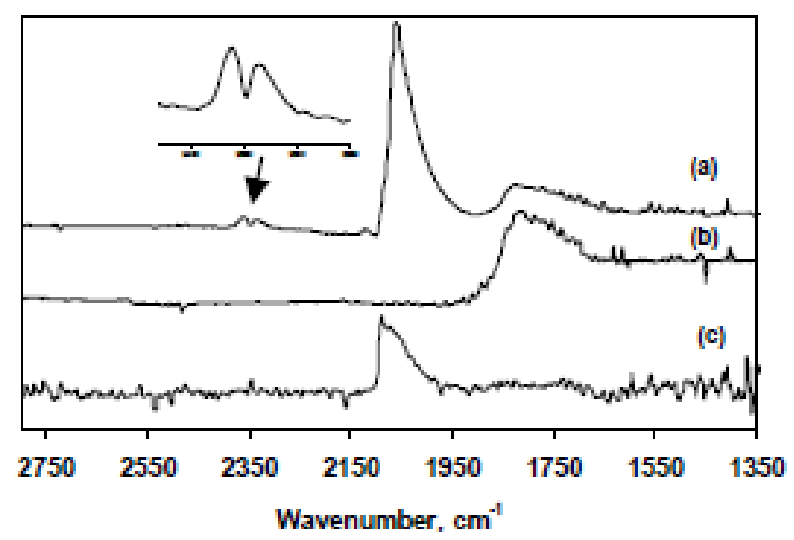

Figure 2. FTIR study for $\mathrm{CO}$ adsorbed over catalysts under $1 \% \mathrm{CO}$ in $\mathrm{He}$ at $100^{\circ} \mathrm{C}$ : (a) $5 \% \mathrm{Pt} / 15 \mathrm{CeO}_{2} / \mathrm{Al}_{2} \mathrm{O}_{3}$, (b) $15 \%$ $\mathrm{CeO}_{2} / \mathrm{Al}_{2} \mathrm{O}_{3}$ and (c) $5 \% \mathrm{Pt} / \mathrm{Al}_{2} \mathrm{O}_{3}$. 


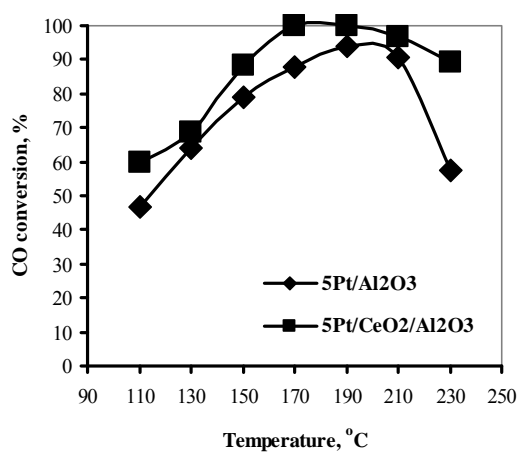

(a)

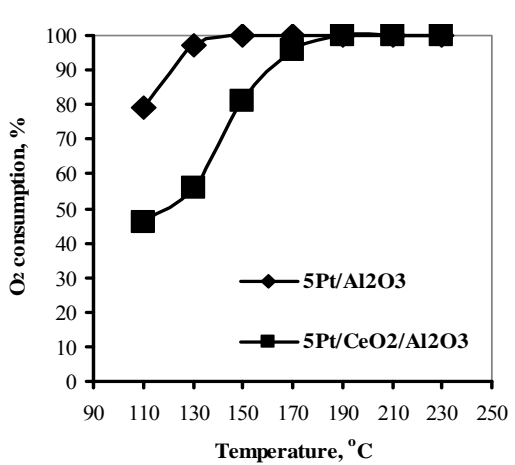

(b)

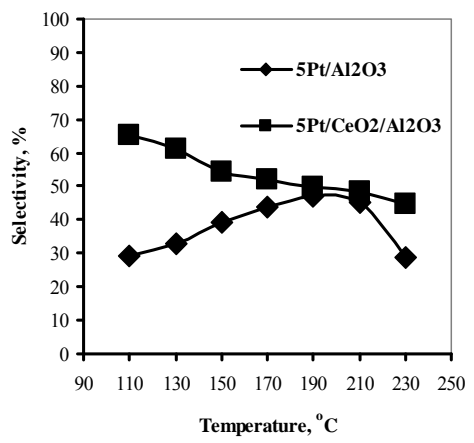

(c)

Figure 3. Comparison of activities to selective $\mathrm{CO}$ oxidation of the $5 \% \mathrm{Pt} / \mathrm{Al}_{2} \mathrm{O}_{3}$ and the $5 \% \mathrm{Pt} / 15 \% \mathrm{CeO}_{2} / \mathrm{Al}_{2} \mathrm{O}_{3}$ catalysts as a function of temperature. Gas composition: $1 \% \mathrm{CO}, 1 \% \mathrm{O}_{2}, 55 \% \mathrm{H}_{2}$ and $\mathrm{He}$ as balance.

to $150^{\circ} \mathrm{C}$. Unlike the $5 \% \mathrm{Pt} / \mathrm{Al}_{2} \mathrm{O}_{3}, \mathrm{O}_{2}$ conversion for the $5 \% \mathrm{Pt} / 15 \% \mathrm{CeO}_{2} / \mathrm{Al}_{2} \mathrm{O}_{3}$ slowly increased from $46 \%$ to $56 \%, 81 \%, 86 \%$ and $100 \%$ when reaction temperature increased from $110^{\circ} \mathrm{C}$ to $130^{\circ} \mathrm{C}, 150^{\circ} \mathrm{C}, 170^{\circ} \mathrm{C}$, and 190 ${ }^{\circ} \mathrm{C}$, respectively. These results led to differences in selectivity for $\mathrm{CO}$ oxidation as shown in Figure 3(c). As mentioned previously, no methane formation was observed under these operating conditions. Consequently, selectivity was defined as the ratio of oxygen used for
$\mathrm{CO}$ oxidation to total oxygen consumed by the reactions. As shown in Figure 3(c), the selectivity's of the two catalysts are different. At $110^{\circ} \mathrm{C}$, selectivity was $29 \%$ for the $5 \% \mathrm{Pt} / \mathrm{Al}_{2} \mathrm{O}_{3}$. This means that oxygen consumed by the reactions mostly goes to $\mathrm{H}_{2}$ oxidation. At the same temperature, selectivity was $65 \%$ for the $5 \% \mathrm{Pt} / 15 \%$ $\mathrm{CeO}_{2} / \mathrm{Al}_{2} \mathrm{O}_{3}$. This means that the presence of ceria in the catalyst enhanced the rate of $\mathrm{CO}$ oxidation. Further increases reaction temperature to $180^{\circ} \mathrm{C}$ increased selectiveity to $44 \%$ for the $5 \% \mathrm{Pt} / \mathrm{Al}_{2} \mathrm{O}_{3}$ but decreased selectivity to $50 \%$ for the $5 \% \mathrm{Pt} / 15 \% \mathrm{CeO}_{2} / \mathrm{Al}_{2} \mathrm{O}_{3}$. At $230^{\circ} \mathrm{C}$, selectivity of both catalysts dropped to $28 \%$ for the $5 \% \mathrm{Pt}$ / $\mathrm{Al}_{2} \mathrm{O}_{3}$ and $45 \%$ for the $5 \% \mathrm{Pt} / 15 \% \mathrm{CeO}_{2} / \mathrm{Al}_{2} \mathrm{O}_{3}$. The decrease of selectivity for both catalysts at high temperatures is due to the competition between $\mathrm{CO}$ oxidation and $\mathrm{H}_{2}$ oxidation reactions. At high temperatures, the $\mathrm{H}_{2}$ oxidation reaction occurs faster than the $\mathrm{CO}$ oxidation reaction [32]. Further investigation of the $5 \% \mathrm{Pt} / 15 \%$ $\mathrm{CeO}_{2} / \mathrm{Al}_{2} \mathrm{O}_{3}$ catalyst was conducted to understand its behavior under different reaction conditions.

\subsection{Space Velocity Effect}

The dependence of $\mathrm{CO}$ conversion and selectivity on flow rate is shown in Figures 4(a)-(c).

Space velocity was increased from 35,000 to 70,000 $\mathrm{cm}^{3} \cdot \mathrm{g}^{-1} \cdot \mathrm{h}^{-1}$. Considering at the same temperatures, increasing the space velocity decreased the $\mathrm{CO}$ conversion and decreased the $\mathrm{O}_{2}$ consumption. With $1 \% \mathrm{CO}, 1 \% \mathrm{O}_{2}$, $20 \% \mathrm{CO}_{2}, 10 \% \mathrm{H}_{2} \mathrm{O}, 55 \% \mathrm{H}_{2}$ and $\mathrm{He}$ as balance, maximum $\mathrm{CO}$ conversion for the low space velocity run was $100 \%$ at $150^{\circ} \mathrm{C}$ while maximum $\mathrm{CO}$ conversion for the high space velocity run was $100 \%$ at $180-190^{\circ} \mathrm{C}$. Selectivity did not change with space velocity at temperatures less than $150^{\circ} \mathrm{C}$. At higher temperatures, selectivity for the low space velocity run was lower than that for the high space velocity run. This result indicates that the use of this catalyst depends on the reaction condition. Low space velocity would obtain high $\mathrm{CO}$ conversion at low temperatures while high space velocity would obtain high $\mathrm{CO}$ conversion at high temperatures.

Activities of $1 \% \mathrm{Pt}-1 \% \mathrm{CeO}_{2}$ over activated carbon [33] were compared with those of $5 \% \mathrm{Pt} / 15 \% \mathrm{CeO}_{2} / \mathrm{Al}_{2} \mathrm{O}_{3}$ in selective $\mathrm{CO}$ oxidation under realistic gas compositions. Although the authors reported that their catalyst is very active to $\mathrm{CO}$ oxidation in $\mathrm{H}_{2}$-excess stream and $\mathrm{CO}$ conversion drastically increased with the presence of $\mathrm{CO}_{2}$, combining both $\mathrm{CO}_{2}$ and $\mathrm{H}_{2} \mathrm{O}$ in the gas feed stream resulted in $\mathrm{CO}$ conversion of $100 \%$ and selectivity to $\mathrm{CO}$ oxidation of $50 \%$ at $150{ }^{\circ} \mathrm{C}$ with space velocity of 24,000 $\mathrm{cm}^{3} \cdot \mathrm{g}^{-1} \cdot \mathrm{h}^{-1}$. Unlike this catalyst, $\mathrm{CO}$ conversion of the $5 \% \mathrm{Pt} / 15 \% \mathrm{CeO}_{2} / \mathrm{Al}_{2} \mathrm{O}_{3}$ decreased with the presence of $\mathrm{CO}_{2}$ in the gas stream. This is due to the carbonate formation blocking the available active sites. However, combining both $\mathrm{CO}_{2}$ and $\mathrm{H}_{2} \mathrm{O}$ in the gas feed enhanced 
the activity of the catalyst especially at low temperatures $\left(<160^{\circ} \mathrm{C}\right)$. Under the realistic gas composition, our catalyst obtained $100 \% \mathrm{CO}$ conversion at $140-150^{\circ} \mathrm{C}$ with selectivity in $\mathrm{CO}$ oxidation of $50 \%-52 \%$ and space velocity of $35,000 \mathrm{~cm}^{3} \cdot \mathrm{g}^{-1} \cdot \mathrm{h}^{-1}$.

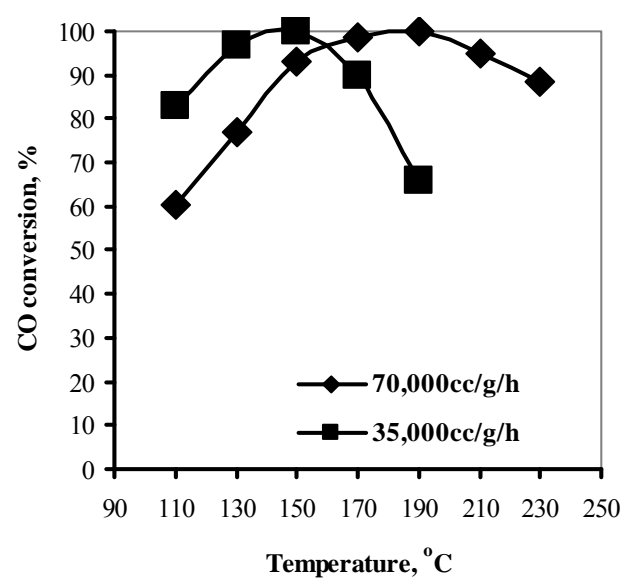

(a)

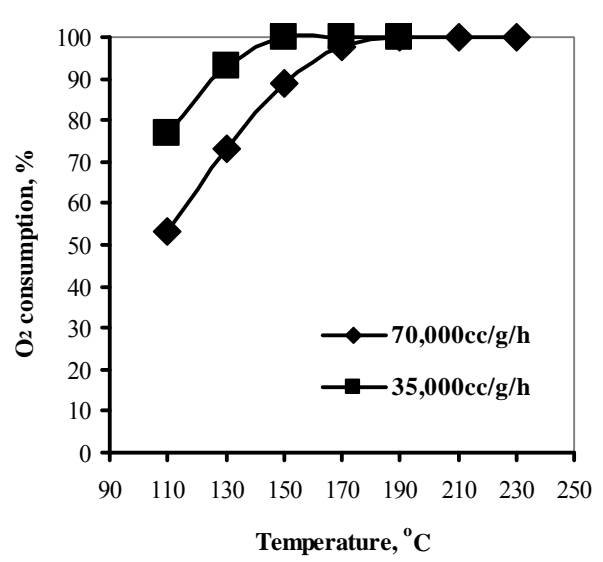

(b)

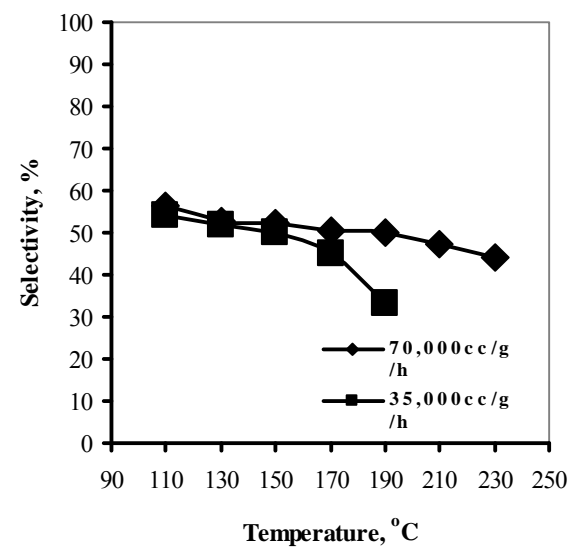

(c)

Figure 4. Dependence of CO conversion and selectivity of $\mathrm{CO}$ oxidation on space velocity and temperature for a $5 \% \mathrm{Pt}$ $/ 15 \% \mathrm{CeO}_{2} / \mathrm{Al}_{2} \mathrm{O}_{3}$. Gas composition: $1 \% \mathrm{CO}, 1 \% \mathrm{O}_{2}$, $10 \% \mathrm{H}_{2} \mathrm{O}, 20 \% \mathrm{CO}_{2}, 55 \% \mathrm{H}_{2}$ and $\mathrm{He}$ as balance.
In our work, $5 \% \mathrm{Pt} / 15 \% \mathrm{CeO}_{2} / \mathrm{Al}_{2} \mathrm{O}_{3}$ demonstrated excellent performance in preferential $\mathrm{CO}$ oxidation. This catalyst is very stable under the realistic gas conditions during $72 \mathrm{hr}$ of use. The higher selectivity in $\mathrm{CO}$ oxidation could obtain under the low $\mathrm{O}_{2}$ concentration.

\section{Conclusions}

The $\mathrm{CO}$ poisoning of PEMFCs is a major problem to deplete the efficiency and energy conversion of PEMFCs. To remove a trace amount of $\mathrm{CO}$ in the reformed gas is essential. In this work, the catalytic performance of promoted platinum over alumina with ceria in selective $\mathrm{CO}$ oxidation in the presence of excess hydrogen has been studied. The addition of ceria improved the catalytic activity in oxidation reactions. It resulted from the oxygen storage property of ceria. Space velocity also affected the $\mathrm{CO}$ conversion. High CO conversion at low temperature was obtained when low space velocity was chosen. Finally, the $5 \% \mathrm{Pt} / 15 \% \mathrm{CeO}_{2} / \mathrm{Al}_{2} \mathrm{O}_{3}$ is an excellent catalyst for removal of trace $\mathrm{CO}$ in reformed gas. It reduces $1 \%$ $\mathrm{CO}$ in the realistic reformed gas to less than $10 \mathrm{ppm}$ with selectivity of $52 \%$ at $180{ }^{\circ} \mathrm{C}$ with space velocity of $70,000 \mathrm{~cm}^{3} \cdot \mathrm{g}^{-1} \cdot \mathrm{h}^{-1}$.

\section{Acknowledgements}

The authors gratefully acknowledge the financial support from Thailand Research Fund (TRF) under the contract \# MRG 4680140.

\section{REFERENCES}

[1] K. Jost, "Gasoline-reforming Fuel Cell," Automotive Engineering , 1997, pp. 151-152.

[2] X. Cheng, Z. Shi, N. Glass, L. Zhang, J. Zhang, D. Song, A.-S. Liu, H. Wang and J. Shen, "A Review of PEM Hydrogen Fuel Cell Contamination: Impacts, Mechanisms, and Mitigation," Journal of Power Sources, Vol. 165, 2007, pp. 739-756. doi:10.1016/j.jpowsour.2006.12.012

[3] S. J. C. Cleghorn, X. Ren, T. E. Springer, M. S. Wilson, C. Zawodzinski, T. A. Zawodzinski and S. Gottesfeld, "PEM fuel Cells for Transportation and Stationary Power Generation Applications," International Journal of $\mathrm{Hy}$ drogen Energy, Vol. 22, 1997, pp. 1137-1144 doi:10.1016/S0360-3199(97)00016-5

[4] W. A. Adams, J. Blair, K. R. Bullock and C. L. Gardner, "Enhancement of the Performance and Reliability of CO Poisoned PEM Fuel Cells," Journal of Power Sources Vol. 145, No. 1, 2005, pp. 55-61. doi:10.1016/j.jpowsour.2004.12.049

[5] S. Gottesfeld, US patent 4,910,099 Preventing CO poisoning in fuel cells (Mar 20, 1990).

[6] Y. H. Kim, S.-D. Yim and E. D. Park, "Selective CO Oxidation in a Hydrogen-rich Stream Over $\mathrm{Ru} / \mathrm{SiO}_{2}$, Catal," Today, Vol. 185, 2012, pp. 143-150. doi:10.1016/j.cattod.2011.07.022 
[7] J. Li, P. Zhu, S. Zuo, Q. Huang and R. Zhou, "Influence of Mn Doping on the Performance of CuO-CeO Catalysts for Selective Oxidation of $\mathrm{CO}$ in Hydrogen-rich Streams," Applied Catalysis A: General, Vol. 381, 2010, pp. 261-266.doi:10.1016/j.apcata.2010.04.020

[8] J. W. Park, J. H. Jeong, W. L. Yoon, C. S. Kim, D. K. Lee, Y.-K. Park and Y. W. Rhee, "Selective Oxidation of $\mathrm{CO}$ in Hydrogen-rich Stream over $\mathrm{Cu}-\mathrm{Ce}$ Catalyst Promoted with Transition Metals," International Journal of Hydrogen Energy, Vol. 30, No. 2, 2005, pp. 209-220. doi:10.1016/j.ijhydene.2004.04.016

[9] Y. -F. Han, M. Kinne, R. J. Behm, “Selective Oxidation of $\mathrm{CO}$ on $\mathrm{Ru} / \gamma-\mathrm{Al}_{2} \mathrm{O}_{3}$ in Methanol Reformate at Low Temperatures, Appl. Catal. B: Environ, Vol. 52, No. 2, 2004, pp. 123-134.doi:10.1016/j.apcatb.2004.03.017

[10] C.-T. Chang, B.-J. Liaw, Y.-P. Chen, Yin-Zu Chen, "Characteristics of $\mathrm{Au} / \mathrm{Mg}_{x} \mathrm{AlO}$ Hydrotalcite Catalysts in CO Selective Oxidation, Journal of Molecular Catalysis A: Chemical, Vol. 300, No. 1-2, 2009, pp. 80-88. doi:10.1016/j.molcata.2008.10.040

[11] M. Kotobuki, A. Watanabe, H. Uchida, H. Yamashita, M. Watanabe, "Development of Pt/ZSM-5 Catalyst with High CO Selectivity for Preferential Oxidation of Carbon Monoxide in a Reformed Gas," Chem. Lett. Vol. 34, 2005, pp. 866-867. doi:10.1246/cl.2005.866

[12] J. L. Ayastuy, A. Gil-Rodríguez, M. P. González-Marcos, M. A. Gutiérrez-Ortiz, Effect of Process Variables on $\mathrm{Pt} / \mathrm{CeO}_{2}$ Catalyst Behavior for the PROX Reaction, International Journal of Hydrogen Energy, Vol. 31, 2006, pp. 2231-2242.doi:10.1016/i.ijhydene.2006.04.008

[13] M. Kotobuki, A. Watanabe, H. Uchida, H. Yamashita, M. Watanabe, "High Catalytic Performance of Pt-Fe Alloy Nanoparticles Supported in Mordenite Pores for Preferential $\mathrm{CO}$ Oxidation in $\mathrm{H}_{2}$-rich Gas, Applied Catalysis A: General, Vol. 307, 2006, pp. 275-283. doi:10.1016/j.apcata.2006.04.003

[14] M. J. Kahlich, H. A. Gasteiger and R. J. Behm, "Kinetics of the Selective $\mathrm{CO}$ Oxidation in $\mathrm{H}_{2}$-Rich Gas on $\mathrm{Pt} / \mathrm{Al}_{2} \mathrm{O}_{3}$," Journal of Catalysis, Vol. 171, 1997, pp. 93-105. doi:10.1006/jcat.1997.1781

[15] I. H. Son, M. Shamsuzzoha and A. M. Lane, "Promotion of $\mathrm{Pt} / \gamma-\mathrm{Al}_{2} \mathrm{O}_{3}$ by New Pretreatment for Low-Temperature Preferential Oxidation of $\mathrm{CO}$ in $\mathrm{H}_{2}$ for PEM Fuel Cells," Journal of Catalysis, Vol. 210, 2002, pp. 460-465. doi:10.1006/jcat.2002.3707

[16] A. Manasilp and E. Gulari, "Selective CO Oxidation over Pt/alumina Catalysts for Fuel Cell Applications, Applied Catalysis B: environmental, Vol. 37, 2002, pp. 17-25. doi:10.1016/S0926-3373(01)00319-8

[17] H. Tanaka, M. Kuriyama, Y. Ishida, S.-I. Ito and K. Tomishige, "Preferential CO Oxidation in Hydrogen-rich Stream over Pt Catalysts Modified with Alkali Metals: Part II. Catalyst Characterization and Role of Alkali Metals," Applied Catalysis A: Generl, Vol. 343, No. 1-2, 2008, pp. 125-133 doi:10.1016/j.apcata.2008.03.029

[18] Y. Li, Q. Fu, M. F., Stephanopoulos, Low-temperature water-gas shift reaction over $\mathrm{Cu}$ - and $\mathrm{Ni}$-loaded cerium oxide catalysts, Applied Catalysis B: Environmental, Vol. 27, No. 3, 2000, pp. 179-191.
doi:10.1016/S0926-3373(00)00147-8

[19] C. Serre, F. Garin, G. Belot and G. Maire, "Reactivity of $\mathrm{Pt} / \mathrm{Al}_{2} \mathrm{O}_{3}$ and $\mathrm{Pt}-\mathrm{CeO}_{2} \mathrm{Al}_{2} \mathrm{O}_{3}$ Catalysts for the Oxidation of Carbon Monoxide by Oxygen: I. Catalyst Characterization by TPR Using CO as Reducing Agent," Journal of Catalysis, Vol. 141, No. 1, 1993, pp. 1-8. doi:10.1006/jcat.1993.1113

[20] A. Martînez-Arias, J. M. Coronado, R. Cataluña, J. C. Conesa and J. Soria, "Influence of Mutual Platinum-Dispersed Ceria Interactions on the Promoting Effect of Ceria for the $\mathrm{CO}$ Oxidation Reaction in a $\mathrm{Pt} / \mathrm{CeO}_{2} / \mathrm{Al}_{2} \mathrm{O}_{3}$ Catalyst," The Journal of Physical Chemistry Letters B, Vol. 102, 1998, pp. 4357-4365. doi:10.1021/jp9805306

[21] A. Parinyaswan, S. Pongstabodee and A. Luengnaruemitchai, "Catalytic Performances of $\mathrm{Pt}-\mathrm{Pd} / \mathrm{CeO}_{2}$ Catalysts for Selective CO Oxidation," International Journal of Hydrogen Energy, Vol. 31, No. 13, 2006, pp. 1942-1949. doi:10.1016/j.ijhydene.2006.05.002

[22] F. A. Silva, D. S. Martinez, J. A. C. Ruiz, L. V. Mattos, C. E. Hori, G. B. Noronha, The Effect of the Use of Cerium-doped Alumina on the Performance of $\mathrm{Pt} / \mathrm{CeO}_{2} / \mathrm{Al}_{2} \mathrm{O}_{3}$ and $\mathrm{Pt} / \mathrm{CeZrO}_{2} / \mathrm{Al}_{2} \mathrm{O}_{3}$ Catalysts on the Partial Oxidation of Methane, Applied Catalysis A: General, Vol. 335, 2008, pp. 145-152. doi:10.1016/j.apcata.2007.11.003

[23] J. C. Brown and E. Gulari, "Hydrogen Production from Methanol Decomposition over $\mathrm{Pt} / \mathrm{Al}_{2} \mathrm{O}_{3}$ and Ceria Promoted $\mathrm{Pt} / \mathrm{Al}_{2} \mathrm{O}_{3}$ Catalysts, Catalysis Communications, Vol. 5, No. 8, 2004, pp. 431-436. doi:10.1016/j.catcom.2004.05.008

[24] I. H. Son and A. M. Lane, Promotion of $\mathrm{Pt} / \gamma-\mathrm{Al}_{2} \mathrm{O}_{3}$ by $\mathrm{Ce}$ for Preferential Oxidation of $\mathrm{CO}$ in $\mathrm{H}_{2}$, Catalysis Letters, Vol. 76, No. 3-4, 2001, pp. 151-154. doi:10.1023/A:1012293311973

[25] I. H. Son, Study of Ce-Pt $/ \gamma-\mathrm{Al}_{2} \mathrm{O}_{3}$ for the Selective Oxidation of $\mathrm{CO}$ in $\mathrm{H}_{2}$ for Application to PEFCs: Effect of Gases, Journal of Power Sources, Vol. 159, 2006, pp. 1266-1273. doi:10.1016/j.jpowsour.2005.12.014

[26] B. E. Yoldas, "Alumina Sol Preparation from Alkoxides," Ceram. Bull, Vol. 54, 1975, pp. 289-290.

[27] J. H. B. J. Hoebink, J. P. Huinink and G. B. Marin, “A Quantitative Analysis of Transient Kinetic Experiments: The Oxidation of $\mathrm{CO}$ by $\mathrm{O}_{2}$ over Pt," Applied Catalysis A: General, Vol. 160, 1997, pp. 139-151. doi:10.1016/S0926-860X(97)00132-4

[28] C. Serre, F. Garin, G. Belot and G. Maire, "Reactivity of $\mathrm{Pt} / \mathrm{Al}_{2} \mathrm{O}_{3}$ and $\mathrm{Pt}-\mathrm{CeO}_{2} \mathrm{Al}_{2} \mathrm{O}_{3}$ Catalysts for the Oxidation of Carbon Monoxide by Oxygen : II. Influence of the Pretreatment Step on the Oxidation Mechanism," Journal of Catalysis, Vol. 141, 1993, pp. 9-20.

doi:10.1006/jcat.1993.1114

[29] D. Liu, G.-H. Que, Z.-X. Wang and Z.-F. Yan, "In Situ FT-IR Study of $\mathrm{CO}$ and $\mathrm{H}_{2}$ Adsorption on a $\mathrm{Pt} / \mathrm{Al}_{2} \mathrm{O}_{3}$ Catalyst," Catalysis Today, Vol. 68, No. 1-3, 2001, pp. 155-160. doi:10.1016/S0920-5861(01)00306-6

[30] A. Holmgren, G. Andersson and D. Duprez, "Interactions of CO with Pt/ceria Catalysts," Applied Catalysis B: En- 
vironmental, Vol. 22, No. 3, 1999, pp. 215-230. doi:10.1016/S0926-3373(99)00047-8

[31] A. Holmgren, D. Duprez, B. Andersson, “A Model of Oxygen Transport in Pt/Ceria Catalysts from Isotope Exchange," Journal of Catalysis, Vol. 182, No. 2, 1999, pp. 441-448.doi:10.1006/jcat.1998.2334

[32] J. L. Ayastuy, M. P. González-Marcos, A. Gil-Rodríguez, J. R. González-Velasco, M. A. Gutiérrez-Ortiz, "Selective
CO Oxidation over $\mathrm{Ce}_{X} \mathrm{Zr}_{1-\chi} \mathrm{O}_{2}$-supported Pt Catalysts, Catalysis Today, Vol. 116, 2006, pp. 391-399. doi:10.1016/j.cattod.2006.05.074

[33] E. Simsek, S. Ozkara, A. E. Aksoylu and Z. I. Onsan, "Preferential CO Oxidation over Activated Carbon Supported Catalysts in $\mathrm{H}_{2}$-rich Gas Streams Containing $\mathrm{CO}_{2}$ and $\mathrm{H}_{2} \mathrm{O}$, Applied Catalysis A: General, Vol. 316, No. 2, 2007, pp. 169-174 doi:10.1016/j.apcata.2006.09.001 